\title{
Entrepreneurship and Human Development: Comparative Analysis for a Challenge to Growth
}

\author{
Luz Stella Vallejo-Trujillo ${ }^{1}$, José Alberto Hernández-Aguilar² ${ }^{2}$, Augusto Renato Pérez-Mayo ${ }^{3}$ \\ ${ }^{1}$ Research Professor Universidad Autónoma del Estado de Morelos -Mexico -UAEM \\ School of Accounting, Management and Organizational Analysis. \\ ${ }^{2}$ Researcher Professor Universidad Autónoma del Estado de Morelos -Mexico -UAEM \\ School of Accounting, Management and Informatics. \\ ${ }^{3}$ Research Professor Universidad Autónoma del Estado de Morelos -Mexico -UAEM \\ School of Accounting, Management and Informatics. \\ Department of Sociology and Organizational Analysis
}

\begin{abstract}
Entrepreneurship refers to ascending roles within the business work (Veciana, 2005), even referred to as "business capital" (Audretsch and Keilbach, 2004; Audretsch, 2007). The purpose of the study was to determine the impact of entrepreneurship, analyzed from Total Entrepreneurial Activity Index-TEA on the Education Development Index EDI and in turn the effect on development and economic growth of a country seen from the Gross Domestic Product (GDP), Gini coefficient and Human Development Index (HDI), which in combination indicators fail to determine the origin of their development and growth. The study design was through document analysis with a comparative qualitative approach, indicators were taken over a period of five years, between 2009-2013, to observe the effect of entrepreneurship into two groups of countries based on the analysis of covariance, by SPSS. It is supported theoretically by using the capabilities approach, which was pioneered by Amartya Sen. The results reported that the Total Entrepreneurial Activity (TEA) has a positive effect on GDP and the GINI, and experience a reverse effect on the EDI and HDI. The largest positive effect on GDP and GINI on TEA is seen in the group of developing countries. It concludes that it is necessary to review public policies and programs of entrepreneurship so that impact on the GDP and the distribution of wealth in Latin America.
\end{abstract}

Keywords: Entrepreneurship, growth, GDP, Human Development Index.

\section{Introduction}

Entrepreneurship in its Anglo-Saxon term makes reference to the ascending roles within the business activities. In the first instance it refers to the person who motivated by a proactive attitude, decides to face the risk of initiating a business activity; a role which later on makes him an entrepreneur, the second role, who acts in the role of an agent of economic, cultural and social change within an environment (Veciana, 2005). As Covarrubias, Planellas, Irizar and others cited in (Uribe \& De Pablo, 2011) point out, there exists a controversy about the notable difference between the two roles, in which the business person does not necessarily come from the transformation of the entrepreneur; given that the latter possess a series of particular skills, personal and entrepreneurial attitudes that may be learned through the entrepreneurial formation from the educational institutions, they may also be innate, characteristics that the entrepreneur does not necessarily have.

From the formative part of the entrepreneur, in numerous investigations the characteristics of an entrepreneur have been resolved, these are: creativity, innovation, the ability to assume risks, persistence in the face of an entrepreneurial project, achievement of objectives to create, initiative, proactivity, common sense, capability of analysis and synthesis, planning, ability of management and operation, among others (Ibarra, 2000)(Banco Interamericano de Desarrollo - BID, 2004)(Contín et al.,2007)(García, et al. 2010). In this respect, it is important to point out that according to Goldfarb et al., (2001), the generation of the new entrepreneurial initiatives depend increasingly on the academic and motivational skills of those who decide to start a business, as mentioned before skills that many times arise from the academic institutions.

Without a doubt, the educational effort impacts on such characteristics, for that reason the function played by the academic institutions is highlighted, as in the case of universities, not only for the formation of skills, but also for its repercussion in the business environment as well as in productivity through the transformation of knowledge, a product of the commercialization of research and even the need for technology transfer generated in them (Guevara \& Calderón, 2009); yet the truth is that in both cases, they become sketches of initiatives for the creation of new businesses that in their majority are developed as micro and small, and in some cases medium enterprises in the different economic sectors.

In this regard, it is worth noting like in the last decades, that the academic institutions have had as their main objective, to provide programs aimed at facilitating entrepreneurship, which no doubt impact on the economy; in which their effect may be evaluated from the Index of Entrepreneurial Activity (Total Entrepreneurial Activity- TEA) which have been reported since 1999 by the School of Business of London, and Babson College. The TEA has become the main indicator that allows monitoring the propensity to such an activity in each country; specifically, it measures the behavior of individuals in relation to the initiative of starting a business. It is applied through a direct survey given to adults between the ages of 18 to 64 years old to near 190 


\section{International Journal of Science and Research (IJSR) \\ ISSN (Online): 2319-7064}

Index Copernicus Value (2013): 6.14 | Impact Factor (2014): 5.611

participating countries (Global Entrepreneurship Research Association - GERA, 2015).

It is appropriate to point out the educational formation in skills and abilities imparted by educational institutions at any level, which also impacts on the Education Development Index-EDI, which provides a global evaluation of the educational system in each country and is calculated from the relation of averages of the net rate of educational level, adult literacy, parity index between sexes and rate of survival in fifth grade of primary school. The result oscillates between 0 and 1 and is monitored by the Development Program of the United Nations in 187 countries (Index 2013) (United Nations-UNESCO, 2011).

This Index of Development of Education - EDI, just as indicators such as: the Index of Entrepreneurial ActivityTEA, Human Development Index-HDI, GINI Coefficient, and Gross Domestic Product, among others have become popular because of their relevance at the time of measuring and comparing the behavior that countries have had in relation to their development, growth, globalization process and welfare, converting them into instruments that facilitate the characterization and qualification of a diversity of phenomena within each country as well as between several countries.

According to Uribe and De Pablo (2011), in Latin America there is proof of important steps in relation to the encouragement of entrepreneurship, opening the possibility to sectors that have been less favored, by the rethinking of these new economic schemes, which allow diminishing the existing social gap.

In addition to being a potentially valuable functionality, entrepreneurship is also a resource. Entrepreneurial abilities, attitudes and aspirations are important requirements in order to be an entrepreneur. The entrepreneurial spirit is an asset because the entrepreneurial behavior oftentimes creates salaries, -employment for others, as well as open other functionalities, that is to say, what can be an intrinsic commodity for a person, may be a means to an end for another

\section{Development and Economic Growth}

Although many governments have seized the contributions of Kliksberg (2001) in relation to the formation of social capital and its impact on economic growth beyond the factors of capital and work; it is true that its effects are long term. It is for this reason that the traditional econometric measurements of economic growth continue being predominant at the time of evaluating the progress of a country, with the purpose of making strategic decision that allow to generate results in the short term. That's why governments have taken measures that motivate the entrepreneurial activity, given its impact on the economy has been important and evident year after year. However, it is worth noting that there exists the need of a greater follow up of these policies, in such a way as the lifecycle of the economic units thus generated be permanent, growing and at the same time contribute to the strengthening of competitivity and entrepreneurial sustainability; as well as the economic and social development; without setting aside the impact that the intangible asset has, over the strengthening of the social fabric, the development and economic growth.

Classical economists like Smith, Ricardo, Malthus and neoclassical such a Schumpeter, Young and even Solow; have tried to explain economic growth from different sources and forms, given their importance. Given its importance, it is necessary to approach the subject of development and economic growth from different angles; involving different indicators aimed at offering relevant information that allow and facilitate a concise analysis of the phenomenon of entrepreneurship in relation to the economic growth of countries.

Until now, the literature has not emphasized the relation between entrepreneurship, educational level and human development. Part of this could be inferred is about the impact that technological innovation, economic growth and productivity improvements have on the indicator, given that they do not automatically translate into human development. Even if entrepreneurship is a determinant of economic growth, it does not imply that it contributes directly on human development, that is to say, we need to take into account that the existing empirical literature argues that the level and rate of entrepreneurship are really determinant and significative of human growth, productivity or employment. In some studies a positive relationship has been observed while in many others no significant or very subtle relationships have been observed, as is indicated by Acs and Szerb (2007: 109) whom even report a negative impact of the entrepreneurship factor and educational level on the economic growth in poor countries. To fill this vacuum and face the lack of an adequate theoretical framework that allows thinking about the relationship between entrepreneurship, educational level and human development, it is possible to address it by the use of the Skills Approach (EC) to the welfare economy that was initiated by Amartya Sen and cited in (Carvajal, 2014). Authors like Alkire (2002) and Robeyns $(2003,2005)$ provide useful introductions in this respect. The EC has provided the base to conceptualize and measure human development, which is also useful as the base for modeling the initiative of entrepreneurship in the development.

In the following section, the Skills Approach (EC) is summarized; where some of its implications are discussed in order to understand the entrepreneurship initiative. Also, a model is proposed in which human development is analyzed as a result of the expansion of the skills of economic agent through a better adaptation of the opportunities to the functionalities of entrepreneurs.

\section{The Intelligibility Nucleus of the Skills Approach (EC)}

Amartya Sen criticizes the dependence of the welfare economy on the income and wealth as the only indicators of human development. According to Sen, the levels of income, wealth and usefulness should not totally be the panacea, since they may not fully reflect the human development. The Human Development, according to Sen,

\section{Volume 4 Issue 11, November 2015}




\section{International Journal of Science and Research (IJSR) \\ ISSN (Online): 2319-7064}

Index Copernicus Value (2013): 6.14 | Impact Factor (2014): 5.611

has to do with the amplification and emancipation of the skills, positive freedoms and equality among people (Sen , 2000).

Skills refer to the "...ability to accomplish a given functionality" of a person. The functionalities are "valuable activities that allow to compensate the welfare of people" (Alkire, 2005: 1). In other words, skills are what people are free to do and functionally achieve in an adequate manner with what it's at hand (Anand et al., 2009: 128).

Thus, to amplify the skills of people means the expansion of their decisions in a positive manner or greater functionality of their "true freedoms". The functionalities include, among many others, "work, rest, knowing how to read and write, that is to say, be a healthy part of a community, to be respected" (Robeyns, 2003: 6)

The essence of EC is to amplify the freedom of people to choose among its functionalities, those that they value more, which could become in functionalities to be reached, if they so desire. According to Robeyns (2003: 7) "In the last instance what is important is what people have the ability of freedom to follow the type of life they want to follow, and do what they want to do and be the person they want to be. Once they effectively have this freedom, they may choose to act on it with their own ideas about the kind of life they wish to live".

Following the model proposed by Anand et al. (2009: 128130), which in turn is based on Sen (1987), it is possible to write about the usefulnes $(\mathrm{U})$ of a person, which derives into a vector of functionalities or functions (f) as $\mathrm{U}=\mathrm{h}(\mathrm{f}(\mathrm{g}(\mathrm{x}))$. This indicates that the functionalities are possible by the access to resources, which for the current effects may include entrepreneurship and its opportunities.

Now, it is possible to go from functionalities to abilities (Anand et al., 2009: 129), taking into account that the potential of a person may be defined as $\mathrm{Q}=\{\mathrm{f}(\mathrm{g}(\mathrm{x}))\}$. This demonstrates that the skills are determined by a set of functionalities a person may choose. This allows arguing that being an entrepreneur is a potential operation, and when it is converted to a pertinent public policy, it may contribute to the expansion of the sets of abilities of people within a community or country. Within these functionalities is the educational variable that boosts the formation of entrepreneurship that may be converted into a public policy. Therefore, its positive freedoms will increase. In this sense, the EC provides a framework of understanding for linking the entrepreneurial factor with the human development.

In some studies it has been observed a positive relationship, in many others, no significative or very subtle relationships have been observed, as indicated by Acs y Szerb (2007: 109), who even report a negative impact of the entrepreneurial factor and the educational level on the economic growth of poor countries. To fill this vacuum, and face the lack of an adequate theoretical framework that allows thinking of a relationship between entrepreneurship, educational level and human development, it is possible to approach it through the use of the Skills Approach (EC) in the welfare economy that was initiated by Amartya Sen cited in (Carvajal, 2014). Other authors like Alkire (2002) and Robeyns $(2003,2005)$ provide useful introductions to this respect. The EC has provided the base to conceptualize and measure human development; which is also useful as a base for modeling the entrepreneurship initiative in the development.

\section{Indicators of the analysis of development: Gross Domestic Product and GINI Coefficient, Index of Human Development-IHD, Education Development Index-EDI and Index of Entrepreneurial Activity-TEA}

Indicators like the Gross Domestic Product-GDP and GINI Coefficient, combined, determine the real quantitative change of the economy in a country. The first, the GDP, measures the percent economic growth of the increase in the production of goods and/or services in a country in a one year period, its increase indicates an improvement in the conditions in the life of an average individual; without necessarily explaining if such growth occurs because the use of more resources or because the use of the same resources with greater efficiency. When the economic growth is produced using more resources, among them the workforce, it does not bring as a result the increase in the income per inhabitant; but if it is accomplished through a more productive use of this, it brings along an increase in the income per inhabitant and the ensuing improvement of the standard of living, on average of the population.

Where appropriate, the Coefficient GINI, measures to what extent the income distribution, or in some cases, the consumption expenditure, among individuals or homes within an economy, deviates from a perfectly equal distribution, which is part of the theoretical approach of Sen. The Lorenz curve shows the accumulated percentages of total income received against the accumulated quantity of recipients, starting from the person or the poorest household. The GINI index measures the surface between the Lorenz curve and a hypothetical line of absolute equality, expressed as a percentage of the maximum surface under the line. Thus, a GINI index of 0 represents a perfect equality, while an index of 100 represents a perfect inequality (World Bank, 2015).

The countries that have shown the greatest economic growth are those that have reported an increase in the Gross Domestic Product- GDP, between one year and another. Otherwise, Latin American countries have shown along their history, indicators with lesser economic growth; however, in the last years, some of these indicators have shown evidence of encouraging movement in this respect.

On the other hand, the Index of Human Development-IHD, as a measure created to highlight the human development in three dimensions: longevity, health and a decent life, authors like Picazzo et al. (2011), propose criteria that allow the evaluation of the development in a country, but not the economic growth alone.

Along these lines, the combination of indicators like the Gross Domestic Product-GDP, the GINI Coefficient and the Index of Human Development-IHD along with the Education Development Index-EDI and the Index of

\section{Volume 4 Issue 11, November 2015}




\section{International Journal of Science and Research (IJSR) \\ ISSN (Online): 2319-7064 \\ Index Copernicus Value (2013): 6.14 | Impact Factor (2014): 5.611}

Entrepreneurial Activity-TEA; allow to determine with certainty if the development and economic growth of a country come from entrepreneurship and how its impact has been. Likewise, when comparing countries with similar characteristics, allows inference to be made about the effect of entrepreneurship on individuals and collectively, ass would be the case in comparing developed countries with greater accumulated economic growth, with Latin American countries, considered emerging or developing and with lesser economic growth.

\section{Method}

In order to know the impact of entrepreneurship, analyzed from the Index of Entrepreneurial Activity-TEA, on the Index of Human Development-IHD and in turn the effect it has on the development and economic growth of a country, a seen from the indicators Gross Domestic Product-GDP, GINI Coefficient and Index of Human Development, which when combined let determine the origin of its development and growth; it is possible to infer the incidence it has over the first, TEA, over the real efficiency in the use of resources and the distribution of wealth in a country and in a group of countries in a comparative manner.

Through the documental analysis with a quantitative approach, the stated indicators were taken, in a period of five years, between 2009 and 2013, in such a way that the effect of entrepreneurship could be observed as it relates to the

growth and development of developed countries such as: Germany, Australia, Canada, Denmark, United States, Holland, Norway, New Zealand, Singapore and Switzerland, as well as the Latin American countries: Argentina, Brazil, Colombia, Costa Rica, Chile, Mexico, Panama and Peru, including Spain. A database was constructed made up by the indicators TEA, GDP, EDI, GINI and HDI, with the most updated information available in the respective virtual sites, data repositories of these indicators, for the realization of the present analysis.

The information was gathered in an Excel spreadsheet, which was later on migrated to SPSS v.22 for its analysis. Once this information was refined, a bivariate correlation analysis among the stated variables was carried out, as recommended by Hernández (2013)

The first analysis was taken from the totality of the sample. Afterwards the base was segmented only with developed countries, then the Latin American countries and then proceeded to compare the results, considering the level of significance found. Finally, a graph was made that allowed to place these countries in clusters that facilitate the visualization of the degree of entrepreneurship (TEA) with respect to the HDI.

\section{Results}

Table 1: Total Sample Correlations

\begin{tabular}{|c|c|c|c|c|c|c|}
\hline & & TEA13 & PIB13 & EDI13 & GINI10 & HDI13 \\
\hline \multirow{3}{*}{ TEA13 } & Pearson Correlation & 1 &, $770^{* *}$ &,$- 802^{* *}$ &, $898^{* *}$ &,$- 856^{* *}$ \\
\hline & Sig. (bilateral) & & ,001 & ,000 &, 000 &, 000 \\
\hline & $\mathrm{N}$ & 15 & 15 & 15 & 13 & 15 \\
\hline \multirow{3}{*}{ PIB13 } & Pearson Correlation &, $770^{* *}$ & 1 &,$- 594^{* *}$ &, $762^{* *}$ &,$- 590^{* *}$ \\
\hline & Sig. (bilateral) &, 001 & &, 007 &, 001 &, 008 \\
\hline & $\mathrm{N}$ & 15 & 19 & 19 & 15 & 19 \\
\hline \multirow{3}{*}{ EDI13 } & Pearson Correlation &,$- 802^{* *}$ &,$- 594^{* *}$ & 1 &,$- 886^{* *}$ &, $957^{* *}$ \\
\hline & Sig. (bilateral) &, 000 &, 007 & & ,000 &, 000 \\
\hline & $\mathrm{N}$ & 15 & 19 & 19 & 15 & 19 \\
\hline \multirow{3}{*}{ GINI10 } & Pearson Correlation &, $898^{* *}$ &, $762^{* *}$ &,$- 886^{* *}$ & 1 &,$- 890^{* *}$ \\
\hline & Sig. (bilateral) &, 000 & ,001 &, 000 & &, 000 \\
\hline & $\mathrm{N}$ & 13 & 15 & 15 & 15 & 15 \\
\hline \multirow{3}{*}{ HDI13 } & Pearson Correlation &,$- 856^{* *}$ &,$- 590^{* *}$ & $957^{* *}$ &,$- 890^{* *}$ & 1 \\
\hline & Sig. (bilateral) &, 000 &, 008 &, 000 &, 000 & \\
\hline & $\mathrm{N}$ & 15 & 19 & 19 & 15 & 19 \\
\hline
\end{tabular}

For the totality of the sample (top-ten countries + Latin American countries), it was found that the TEA is directly correlated with the GDP and GINI at 99\%, and inversely correlated to the EDI and the HDI at the same level of significance (99\%). This indicates that the TEA impacts directly on the GDP and GINI, while it has an inverse effect on the EDI and HDI (see the previous table). 


\section{International Journal of Science and Research (IJSR) \\ ISSN (Online): 2319-7064}

Index Copernicus Value (2013): 6.14 | Impact Factor (2014): 5.611

Table 2: Developed countries correlations

\begin{tabular}{|c|c|c|c|c|c|c|}
\hline \multicolumn{2}{|c|}{} & TEA13 & PIB13 & EDI13 & GINI10 & HDI13 \\
\hline \multirow{4}{*}{ TEA13 } & Pearson Correlation & 1 &, 437 &,- 356 &, 820 &,- 632 \\
\cline { 2 - 7 } & Sig. (bilateral) & &, 327 &, 433 &, 089 &, 128 \\
\cline { 2 - 7 } & $\mathrm{N}$ & 7 & 7 & 7 & 5 & 7 \\
\hline \multirow{4}{*}{ PIB13 } & Pearson Correlation &, 437 & 1 &,- 360 &, $848^{*}$ &,- 006 \\
\cline { 2 - 7 } & Sig. (bilateral) &, 327 & &, 307 &, 033 &, 988 \\
\cline { 2 - 7 } & $\mathrm{N}$ & 7 & 10 & 10 & 6 & 10 \\
\hline \multirow{4}{*}{ EDI13 } & Pearson Correlation &,- 356 &,- 360 & 1 &,- 209 &, 589 \\
\cline { 2 - 7 } & Sig. (bilateral) &, 433 &, 307 & &, 692 &, 073 \\
\cline { 2 - 7 } & $\mathrm{N}$ & 7 & 10 & 10 & 6 & 10 \\
\hline \multirow{3}{*}{ GINI10 } & Pearson Correlation &, 820 &, $848^{*}$ &,- 209 & 1 &,- 239 \\
\cline { 2 - 7 } & Sig. (bilateral) &, 089 &, 033 &, 692 & &, 649 \\
\cline { 2 - 7 } & $\mathrm{N}$ & 5 & 6 & 6 & 6 & 6 \\
\hline \multirow{3}{*}{ HDI13 } & Pearson Correlation &,- 632 &,- 006 &, 589 &,- 239 & 1 \\
\cline { 2 - 7 } & Sig. (bilateral) &, 128 &, 988 &, 073 &, 649 & \\
\cline { 2 - 7 } & $\mathrm{N}$ & 7 & 10 & 10 & 6 & 10 \\
\hline
\end{tabular}

*. The correlation is significant at the level 0,05 (bilateral).

In the developed countries, top ten, it was identified that the index TEA is not correlated with the GDP, the IDE, the GINI or the HDI in a significant manner. This allows us to infer that the TEA does not impact on these last indicators in these countries.

On the other hand, in the Latin American countries the index TEA (Total Entrepreneurial Activity) is correlated at 95\% with the GDP $(0,788)$ and the GINI $(0,796)$, which means that the entrepreneurial activity has an important effect on the Gross Domestic Product, as well as the indicator of the distribution of wealth. In the same manner, it is correlated inversely to the EDI and the HDI, but this correlation is not significant.

Table 3: Correlations for Latin American countries

\begin{tabular}{|c|c|c|c|c|c|c|}
\hline & & TEA13 & PIB13 & EDI13 & GINI10 & HDI13 \\
\hline \multirow{3}{*}{ TEA13 } & Pearson Correlation & 1 &, $788^{*}$ &,- 580 &, $796^{*}$ &,- 692 \\
\hline & Sig. (bilateral) & &, 020 &, 132 & ,018 &, 057 \\
\hline & $\mathrm{N}$ & 8 & 8 & 8 & 8 & 8 \\
\hline \multirow{3}{*}{ PIB13 } & Pearson Correlation & $788^{*}$ & 1 &,- 456 & ,603 &,- 530 \\
\hline & Sig. (bilateral) &, 020 & & ,217 & ,086 & ,142 \\
\hline & $\mathrm{N}$ & 8 & 9 & 9 & 9 & 9 \\
\hline \multirow{3}{*}{ EDI13 } & Pearson Correlation &,- 580 &,- 456 & 1 &,$- 690^{*}$ & $928^{* *}$ \\
\hline & Sig. (bilateral) &, 132 & ,217 & &, 040 &, 000 \\
\hline & $\mathrm{N}$ & 8 & 9 & 9 & 9 & 9 \\
\hline \multirow{3}{*}{ GINI10 } & Pearson Correlation &, $796^{*}$ & ,603 &,$- 690^{*}$ & 1 &,$- 710^{*}$ \\
\hline & Sig. (bilateral) & ,018 & ,086 &, 040 & &, 032 \\
\hline & $\mathrm{N}$ & 8 & 9 & 9 & 9 & 9 \\
\hline \multirow{3}{*}{ HDI13 } & Pearson Correlation &,- 692 &,- 530 &, $928^{* *}$ &,$- 710^{*}$ & 1 \\
\hline & Sig. (bilateral) &, 057 & ,142 &, 000 &, 032 & \\
\hline & $\mathrm{N}$ & 8 & 9 & 9 & 9 & 9 \\
\hline \multicolumn{7}{|c|}{$\begin{array}{l}\text { *. The correlation is significant at level } 0,05 \text { (bilateral). } \\
\text { **. The correlation is significant at level } 0,01 \text { (bilateral). } \\
\text { When crossing the TEA with respect to the HDI, two groups may be distinguished, the ones that have a high HDI but low } \\
\text { TEA (countries with high development) and the Latin American countries (with the exception of Spain) with a low HDI } \\
\text { but a high TEA. Argentina and Chile have the highest values of HDI (see next figure). }\end{array}$} \\
\hline
\end{tabular}




\section{International Journal of Science and Research (IJSR) \\ ISSN (Online): 2319-7064}

Index Copernicus Value (2013): 6.14 | Impact Factor (2014): 5.611

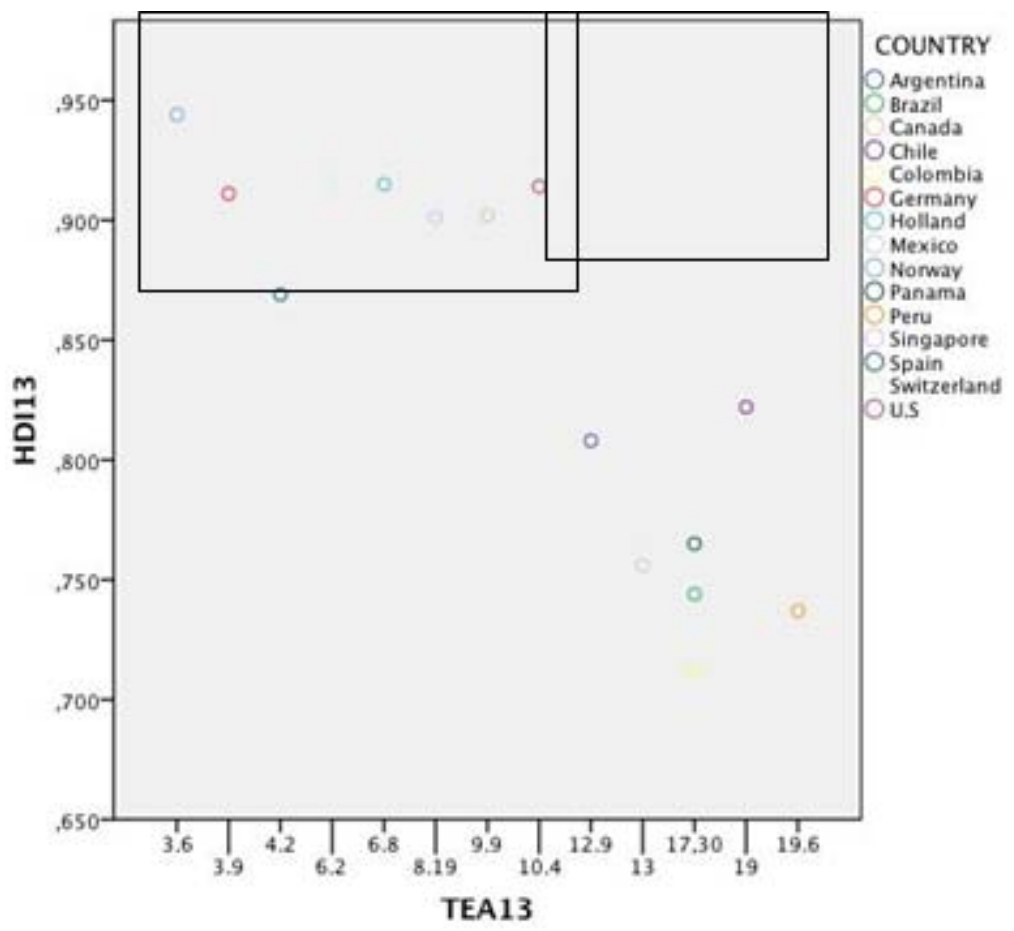

Figure 1: TEA 2013 versus HDI 2013

In Figure 1, it may be appreciated two large clusters, the upper left corresponds to countries with a high index of human development, which correspond to the countries designated in this work as "top ten" and the lower right which corresponds to developing countries, which in turn have a greater TEA index.

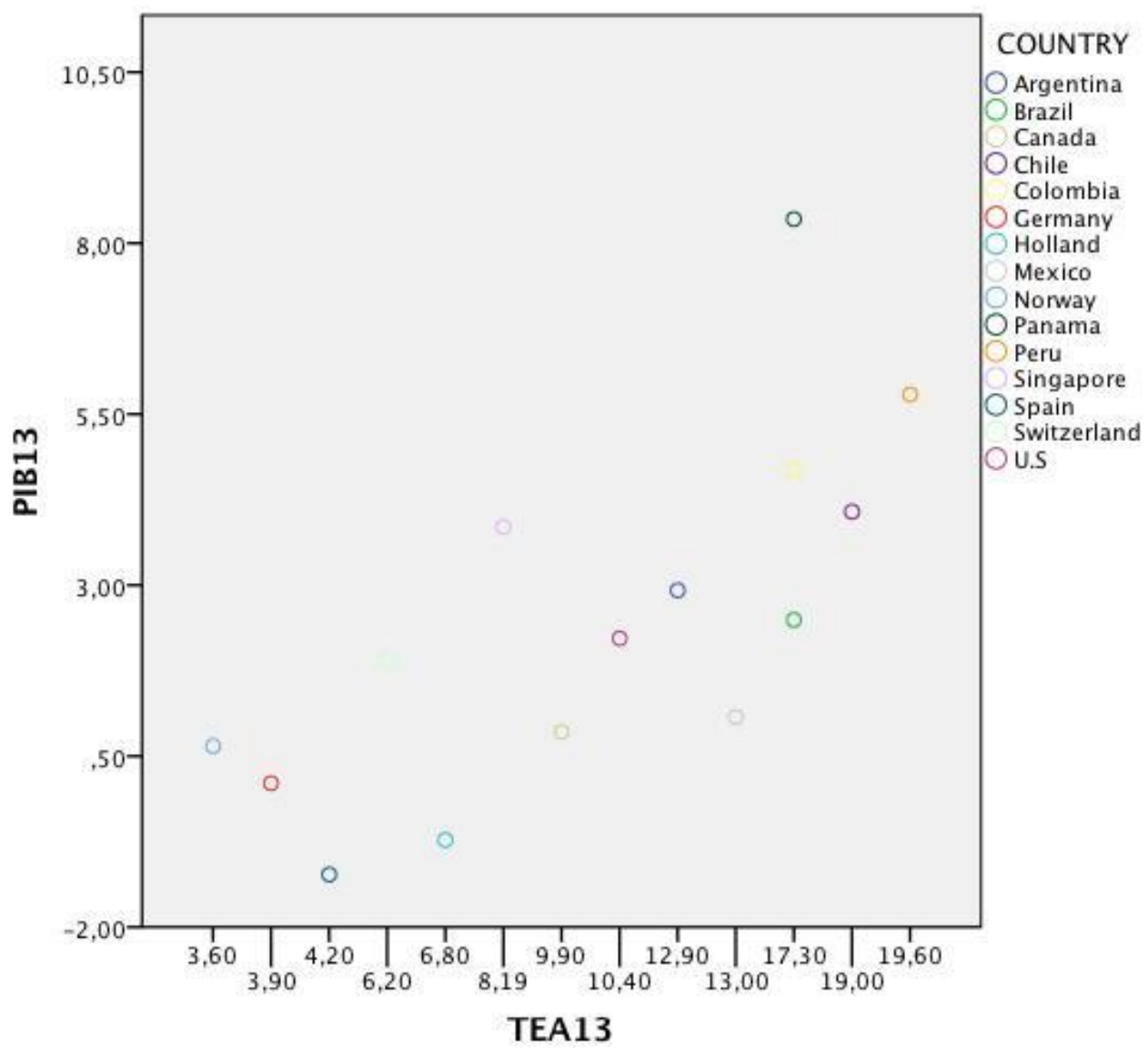

Figure 2:TEA 2013 versus PBI 2013

Volume 4 Issue 11, November 2015 www.ijsr.net 


\section{International Journal of Science and Research (IJSR) \\ ISSN (Online): 2319-7064 \\ Index Copernicus Value (2013): 6.14 | Impact Factor (2014): 5.611}

In Figure 2, it may be appreciated the graph of the TEA with respect to the GDP, it is observed that the greater the TEA, the greater the increase in the GDP. In Table 4, the simulation of the impact of the TEA on the GDP is shown. It may be observed that a proposed linear regression model allows modeling the effect of the TEA on the GDP. The independent variable is TEA 13.
Table 4: Summary of model and parameters estimations

\begin{tabular}{|c|c|c|c|c|c|c|c|}
\hline \multicolumn{7}{|c|}{ Dependent variable: PIB13 } \\
\hline Equation & \multicolumn{5}{|c|}{ Summary of model } & \multicolumn{2}{|c|}{$\begin{array}{c}\text { Parameters } \\
\text { estimations }\end{array}$} \\
\cline { 2 - 8 } & $\begin{array}{c}\mathrm{R} \\
\text { square }\end{array}$ & $\mathrm{F}$ & gl1 & gl2 & Sig. & Constant & b1 \\
\hline Lineal &, 594 & 18,984 & 1 & 13 &, 001 & $-1,426$ &, 344 \\
\hline
\end{tabular}

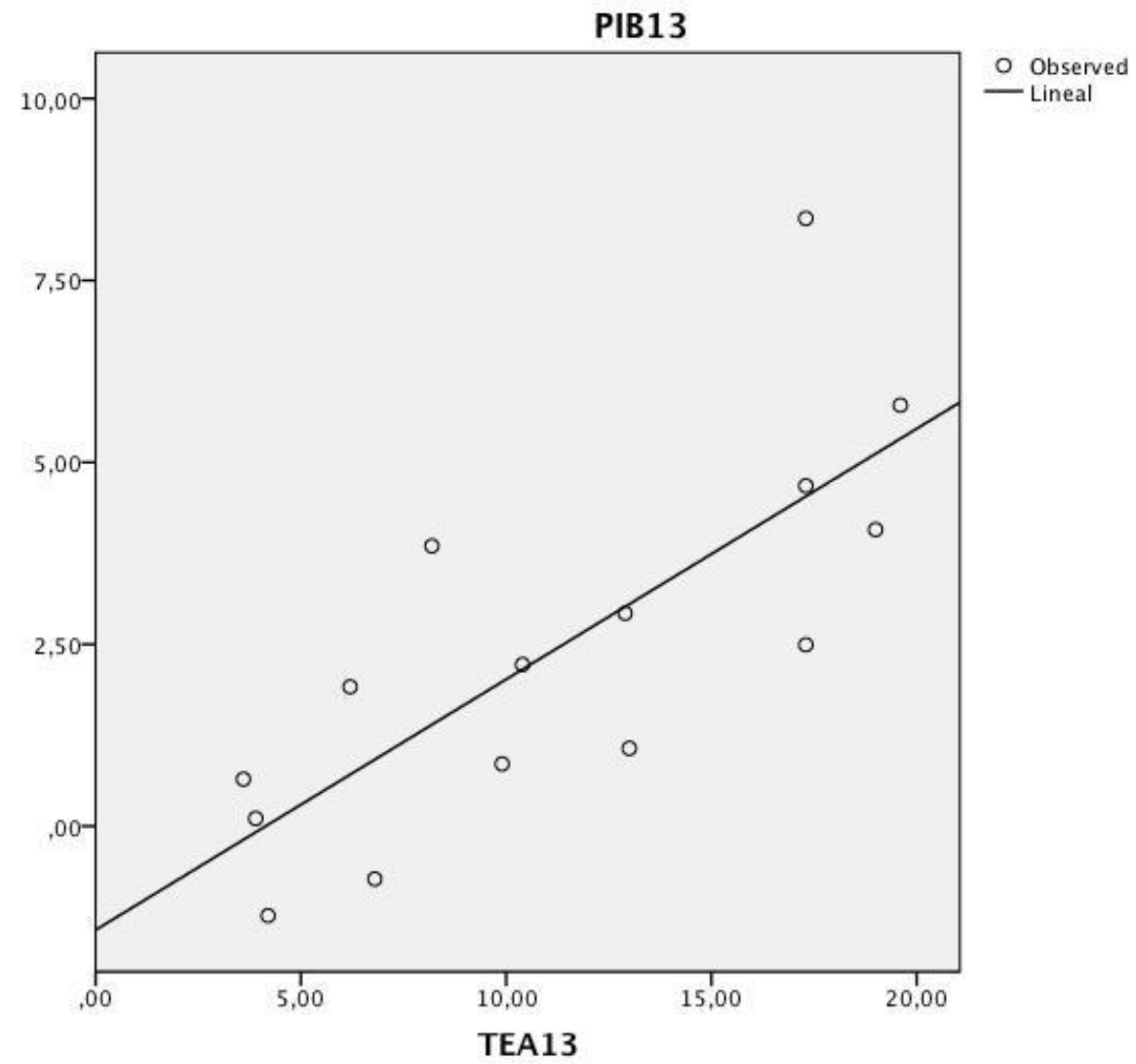

Figure 3: Regression analysis TEA - PIB

Figure 3 shows the effect of the TEA in the GDP, that while there are slight variations, in general the model adjusts to a straight line given by: GDP $=0,344 *($ TEA) -1.426 .

\section{Conclusions and Further Work}

The total entrepreneurial activity (TEA) has a positive effect on the GDP and in the GINI, and experiences an inverse effect on the EDI and HDI. The major positive effect of the TEA on the GDP and GINI may be appreciated in the Latin American countries. This work intends to complement with an analysis by markets, for example Mercosur, North America, European Community, in order to distinguish the effect of the TEA by economic zone.

From the finding of the inverse relationship between the increase in the entrepreneurial activity and the behavior of the Index of Economic Development, it permits to infer about the necessity of revising the relationship there is between public policies in academic subjects, and the set of economic policies that have originated in this respect in Latin American countries.
If it is to be expected that the education impinges in the growth and economic development, the educational policies must contemplate actions of linking with productive and sustainable projects that not only contemplate as its objective the entrepreneurial activity, but also it integration into productive chains that make it viable in the set of the economy in the mid and long terms. In this sense, it is advisable the incorporation to the educational models of the institutions of higher learning, subjects related with the formation of an entrepreneurial profile, in addition to the capacity of integration and social responsibility to its local, national and regional environment.

As far as it's concerned, the economic policy keeps having pending the creation and reinforcement of value chains starting from the incorporation from the microeconomic level, of entrepreneurial activities branched to the internal market as well as to regional and external markets. In that sense, Sen and Anand are not mistaken, as they show that the skills are determined by the set of functionalities that a person may choose. This permits to argue that being an entrepreneur is a potential functioning, and when it becomes a pertinent public policy, it may contribute to the expansion of the sets of skills of people in a community or country. Therefore, one of these functionalities is the educational 


\section{International Journal of Science and Research (IJSR) \\ ISSN (Online): 2319-7064}

Index Copernicus Value (2013): 6.14 | Impact Factor (2014): 5.611

variable that encourages the formation of an entrepreneur. If it is done, the positive liberties of the entrepreneurs will increase in developing countries. In this regard, the theory of the Skills Approach (EC) provides a framework for the understanding for the linking of the entrepreneurial factor with the human development and the educational growth.

\section{References}

[1] Anand, P., Hunter, G., Carter, I., Dowding, K., Guala, F., Van Hees, M., 2009. The development of capability indicators. Journal of Human Development and Capabilities 10 (1), 125-152.

[2] Acs, Z.J., Szerb, L. (2007). Entrepreneurship, economic growth and public policy. Small Business Economics. 28, 109-122.

[3] Alkire, S. (2002). Valuing freedoms: Sen's capability approach and poverty reduction. Oxford University Press, Oxford.

[4] Alkire, S. (2005). Valuing freedoms: Sen's capability approach and poverty reduction. New York, USA: Oxford University Press.

[5] Audretsch, D.B. (2007). Entrepreneurship capital and economic growth. Oxford Review of Economic Policy. $23,63-78$.

[6] Audretsch, D.B., Keilbach, M.C. (2004). Entrepreneurship capital and economic performance'. Regional Studies.38 (8), 949-959.

[7] Banco Interamericano de Desarrollo - BID. (2004). El Nuevo Rostro Empresarial: Indagación sobre el Empresario Juvenil en América Latina y el Caribe. (A. Omega, Ed.) Bogotá: Banco Interamericano de Desarrollo.

[8] Carvajal, M. (Primer semestre de 2014). El enfoque de capacidad de Amartya Sen y sus limitaciones para la ciudadanía y la sociedad civil. Araucaria. Revista Iberoamericana de Filosofía, Política y Humanidades, 31, 85-103.

[9] Contín, I., Larraza, M., \& Mas, I. (Abri-Junio de 2007). Características distintitivas de los emprendedores y empresarios establecidos: evidencia a partir de los datos REM Navarra. Revista de Empresa(20).

[10] García, C., Martínez, A., \& Fernández, R. (2010). Características del emprendedor influyentes en el proceso de creación empresarial y en el éxito esperado. Revista europea de dirección y economía de la empresa , 19(2), 31-47.

[11] Global Entrepreneurship Research Association - GERA. (2015). Global Entrepreneurship Monitor 2014 Global Report.

[12] Goldfarb, B., Henrekson, M., \& Rosenberg, N. (Febrero de 2001). Demand vs. Supply Driven Innovations; Us and Swedish Experiences in Academic Entrepreneurship. Journal of Technology Transfer, O035.

[13] Guevara, M., \& Calderón, O. (Enero-Diciembre de 2009). Experiencias de incorporación de emprendedurismo en Instituciones de Educación Superior. Revista Centroamericana de Administración Pública-ICAP(56-57), 171-182.

[14]Hernández Aguilar, J. (2013). Generación, análisis y tratamiento de información en las organizaciones (1a edición ed.). Cuernavaca, Morelos, México: UAEM Juan Pablos Editor.

[15] Ibarra, D. (2000). Los primeros pasos al mundo empresarial: una guía para emprendedores. México: Prentice Hall.

[16] Index, E. (15 de Noviembre de 2013). Human Developed Reports. Recuperado el 27 de Mayo de 2015, de United Nations Development Programme: hdr.undp.org/es/content/education-index

[17]Kliksberg, B. (2001). El Capital Social. Caracas, Venezuela: Panapo.

[18] Organización de Naciones Unidas - UNESCO. (2011). Informe de seguimiento de la EPT en el Mundo. Organización de Naciones Unidas - UNESCO, Instituto de Estadística.

[19]Picazzo, E., Gutiérrez, E., Infante, J., \& Cantú, P. (Enero-Junio de 2011). La teoría del desarrollo humano y sustentable: hacia el reforzamiento de la salud como un derecho y libertad universal. Estudios Sociales, 19(37).

[20] Robeyns, I. (2003). The Capability Approach: An Interdisciplinary Introduction. Mimeo: Amsterdam School of Social Sciences, Dec

[21] Robeyns, I., 2005. The capabilities approach: a theoretical survey. Journal of Human Development. 6 (1), 93-114.

[22] Sen, A. (June de 2000). Social Exclusion: Concept, Application, and Scrutiny. Social Development Papers No. 1, 54. (A. D. Bank, Ed.) Manila, Philippines: Asian Development Bank.

[23] Sen, A. (s.f.). Commodities and Capacibilties. The Canadian Journal of Ecn.

[24] Uribe, J., \& de Pablo, J. (Diciembre de 2011). Revisando el Emprendedurismo. Boletín Económico de ICE (3021).

[25] Veciana, J. (2005). La creación de empresa: un enfoque gerencial. Colección de estudios económicos La Caixa.

[26] World Bank. (2015, September 10 ). Banco Mundial. Retrieved from http://www.bancomundial.org/ 